\title{
Effect of sediment composition on methane concentration and production in the transition zone of a mangrove (Sepetiba Bay, Rio de Janeiro, Brazil)
}

\author{
Marinho, CC. ${ }^{a}$, Campos, EA. ${ }^{a *}$, Guimarães, JRD. ${ }^{b}$ and Esteves, FA. ${ }^{a}$ \\ ${ }^{a}$ Laboratório de Limnologia, Departamento de Ecologia, Instituto de Biologia - IB, Centro de Ciências da Saúde - CCS, \\ Universidade Federal do Rio de Janeiro - UFRJ, Ilha do Fundão, CEP 21941-902, Rio de Janeiro, RJ, Brazil \\ 'Laboratório de Traçadores W. C. Pfeiffer, Instituto de Biofísica Carlos Chagas Filho - IBCCF, \\ Centro de Ciências da Saúde - CCS, Universidade Federal do Rio de Janeiro - UFRJ, \\ Ilha do Fundão, CEP 21941-902, Rio de Janeiro, RJ, Brazil \\ *e-mail: elidacamp@gmail.com; clcamar@biologia.ufrj.br
}

Received May 5, 2011 - Accepted September 15, 2011 - Distributed August 31, 2012

(With 3 figures)

\begin{abstract}
The aim of this research was to evaluate the effect of sediment composition on methane $\left(\mathrm{CH}_{4}\right)$ dynamics in sediments of different areas in the transition zone between a mangrove and the sea. This research was conducted in a mangrove at Coroa Grande, on the southern coast of Rio de Janeiro. Samples were collected at three stations: (1) region colonised by Rhizophora mangle L. on the edge of the mangrove, (2) region colonised by seagrasses and (3) infra-littoral region without vegetation. Samples were collected from the surface layer of the sediment to determine the concentrations of nutrients $(\mathrm{C}, \mathrm{N}$ and $\mathrm{P})$ and $\mathrm{CH}_{4}$ concentration and production. We observed that concentrations of $\mathrm{CH}_{4}$ and carbon $(\mathrm{C})$ were significantly higher $(\mathrm{p}<0.05)$ in station 1 than station 3 . The molar ratios $(\mathrm{C}: \mathrm{N}, \mathrm{C}: \mathrm{P}$ and $\mathrm{N}: \mathrm{P})$ suggest that the origin of the substrate is mainly autochthonous. Methanogenesis was initially low, possibly due to competition between methanogens and sulfate reducers, and increased significantly $(\mathrm{p}<0.05)$ on the twenty-sixth day in the sediment of station 1, probably due to higher organic matter $(\mathrm{OM})$ availability in this region. Results indicate that methanogenic activity observed herein is not regulated by the amount or quality of $\mathrm{OM}$, but by other factors. The concentration of $\mathrm{CH}_{4}$ in the sea-land ecotone at Mangrove Coroa Grande is a function of available OM suggesting a possible inhibition of methanotrophy by intense oxygen consumption in the soil surface covered by detritus of Rhizophora mangle vegetation.
\end{abstract}

Keywords: ecotone, methanogens, OM, macrophytes, Rhizophora.

\section{Efeito da composição do sedimento sobre a concentração e a produção do metano na zona de transição de um mangue tropical, na Baía de Sepetiba-RJ, Brasil}

\section{Resumo}

O objetivo desta pesquisa foi avaliar a dinâmica do metano $\left(\mathrm{CH}_{4}\right)$ no sedimento em diferentes áreas na região de transição entre a borda do manguezal e o mar, em função da composição do sedimento. A pesquisa foi realizada no Manguezal de Coroa Grande, no litoral sul do Estado do Rio de janeiro. Foram coletadas amostras em três estações: (1) região colonizada por Rhizophora mangle L. na borda do mangue, (2) região colonizada por macrófitas, e (3) região sem vegetação, permanentemente inundada pelo mar. Foram coletadas amostras da fração superficial do sedimento para determinação da concentração de nutrientes $\left(\mathrm{C}, \mathrm{N}\right.$ e P), e da concentração e da produção de $\mathrm{CH}_{4}$. Foi observado que as concentrações de $\mathrm{CH}_{4}$ e carbono $(\mathrm{C})$ foram significativamente maiores $(\mathrm{p}<0,05)$ na estação 1 , em relação à estação 3. Com relação às razões molares (C:N, C:P e N:P), estas indicam que a origem da composição do substrato é principalmente autóctone. Quanto à metanogênese, foram observados, inicialmente, baixos valores de $\mathrm{CH}_{4}$ produzido, indicando provável competição entre metanogênicos e sulfatorredutores. Seguiu-se, então, um significativo aumento $(\mathrm{p}<0,05)$ da metanogênese no $26^{\circ}$ dia, no sedimento da estação 1 , provavelmente em função da maior disponibilidade de matéria orgânica (MO) nessa região. Os resultados mostram que a atividade metanogênica observada pela presente pesquisa não é regulada pela quantidade e a qualidade da $\mathrm{MO}$ e sim por outros fatores. A concentração de $\mathrm{CH}_{4}$ no ecótono mar-terra no manguezal de Coroa Grande, ocorre em função da MO disponível, sugerindo possível inibição da metanotrofia, em razão de intenso consumo de oxigênio na superfície do solo coberto pelo detrito da vegetação de Rhizophora mangle.

Palavras-chave: ecótono, metanogênicos, MO, macrófitas, Rhizophoras. 


\section{Introduction}

Methane is considered one of the most important greenhouse effect gases due to its high global warming potential compared to $\mathrm{CO}_{2}$ (IPCC, 2001). Methane presents capacity of infrared radiation absorption 21 times higher than $\mathrm{CO}_{2}$ per mass unit (El-Fadel and Massoud, 2001). According to the IPCC (2007), the concentration of atmospheric methane increased from $715 \mathrm{ppb}$ in the pre-industrial period to $1732 \mathrm{ppb}$ in the early 1990, and 1774 ppb in 2005.

Methanogenesis is a microbiological degradation of organic compounds into methane, controlled by the absence of oxygen and substrate availability (Segers, 1998). This nutrient cycling is performed by strict anaerobe organisms that belong to the Archea domain, known as methanogens (Mohanraju et al., 1997), which metabolise simple organic substrates. Most of them use only one or two types of substrates (Ferry, 1993), with two main substrates: (1) carbon dioxide with molecular hydrogen, (2) formate and (3) acetate (Mohanraju et al., 1997).

Several factors may influence methanogenesis, such as salinity, temperature, $\mathrm{pH}$, substrate availability and microbial interaction with other anaerobic metabolic groups, such as iron $\left(\mathrm{Fe}^{3+}\right)$ reducing bacteria, acetogenic and sulfate reducing bacteria. Methanogens may, for example, compete for substrate with sulfate-reducers in the presence of sulfate (Ferry, 1993), that in coastal environments tend to have higher concentrations due to the proximity to the sea. In these ecosystems, sulfate-reduction may be favoured in detriment of methanogenesis, because it is more energetically advantageous in relation to substrates common to both types of microorganisms (Lyimo et al., 2002a). However, these processes may coexist in presence or absence of non-competitive substrates, which are organic osmorregulators that tend to occur as an adaptative response to environments with high salinity (Ferry, 1993). Substrate availability may also be high enough to maintain both processes (Purvaja et al., 2004). This is common in environments altered by anthropogenic activities, which have increased capacity of methane production by having higher amounts of organic matter (OM), increasing bacterial metabolism in the sediment (Strangmann et al., 2008). According to Schubert et al. (2010) methane produced in anaerobic sediments of the ecosystem can be oxidised in the aerobic zone by methanotrophic bacteria, or even in anaerobiosis by Archea methanogens, often related to sulfate reduction (Meulepas et al., 2010; Hinrichs et al., 2000). Thus, the relation between production and consumption of methane allows a system to have an intensive production without great concentration, and hence, with low emission of this gas to the atmosphere (Giani et al., 1996).

Mangroves are coastal ecosystems which occur in the areas of transition between marine and terrestrial environments subjected to tidal variation (Schaeffer-Novelli, 1995). They are characterised by low flora diversity, with species that are adapted to the salinity fluctuation common to mangrove forests (Tomlinson, 1994), and by high production and accumulation of OM. This makes mangroves highly important in the maintenance of food chains that support intense microbial activity in sediment, formed by autochthonous or allochthonous fine-grained material, water and salts (Schaeffer-Novelli, 1995). Due to this composition, the sediment is generally organic, not very consistent and with little or no oxygen (Schaeffer-Novelli et al., 2002), making fermentation the main process of OM decomposition (Krupadam et al., 2007), which provides production of hydrogen sulfide (Tomlinson, 1994), nitrous oxide and methane (Kreuzwieser et al., 2003; Allen et al., 2007; Krithika et al., 2008; Purvaja et al., 2004; Krupadam et al., 2007). Although the aspect of the mangrove forest soil seems quite homogeneous, areas with different vegetation covers have different compositions (Lacerda et al., 1995). According to Nguyen et al. (2010), sediments rich in labile organic matter tend to have higher methane production than refractory substrates formed by $\mathrm{OM}$. According to the same author, sediments that have $\mathrm{C}: \mathrm{N}$ ratio $<10$ have a higher potential for methane formation when compared to those with $\mathrm{C}: \mathrm{N}$ ratio $>10$.

In the present research, conducted in a mangrove forest located in southeast Brazil, we hypothesised that the methanogenic activity in sediment of the mangrove transition zone with the sea is controlled by the amount of organic matter in sediment, depending on the concentration of nutrients and its quality, through the molar ratios between nutrients. To test this hypothesis, we: (1) determined C, $\mathrm{N}$ and $\mathrm{P}$ and their the molar ratios $\mathrm{C}: \mathrm{N}, \mathrm{C}: \mathrm{P}$ and $\mathrm{N}: \mathrm{P}$ in sediments colonised by different types of vegetation and in sediments without vegetation in the mangrove-sea transition area, (2) evaluated the dynamics of methane in the sediment in these same regions, through the determination of its concentration and production.

\section{Methodology}

\subsection{Study area}

This study was conducted in Coroa Grande mangrove, Itaguaí district, located along the northern coast of Sepetiba Bay, about $100 \mathrm{~km}$ from the city of Rio de Janeiro, southeastern Brazil. Sepetiba Bay has an area of $447 \mathrm{~km}^{2}$ with an average depth of about $6.0 \mathrm{~m}$. The tides vary between $0.6 \mathrm{~m}$ and $2.6 \mathrm{~m}$.

The border area of the mangrove forest is mainly colonised by Rhizophora mangle L., a few individuals of Laguncularia racemosa Gaertn. and Avicennia schaueriana Saptf and Leech. The inner part of the mangrove is colonised by Laguncularia rancemosa and Avicennia schaueriana only (Coimbra, 2003), and the area above the edge of the mangrove is colonised by seagrasses. The sediment is characterised by fractions of sand in the region without vegetation (an area of transition from sea to mangrove) and silty-clay in the area of mangrove forest, with the highest percentage of organic matter in the latter (Coimbra, 2003).

The number of inhabitants of Sepetiba Bay has increased greatly in recent years due to industrial growth in the 
region over the last decades, which has been reported as the main cause of deterioration of the bay water quality (Molisani et al., 2004). This large demographic expansion raises environmental pressures such as high inputs of domestic sewage and of agriculture effluents, sand extraction and others, affecting the bay's ecosystem, including mangroves (Coimbra, 2003).

\subsection{Sampling}

Sampling was carried out in May 2008, during low tide through a $50 \mathrm{~m}$ transect perpendicular to the sea. Along the transect, three sampling stations were established: (1) edge of the area colonised by Rhizophora mangle mangrove, (2) area colonised by seagrasses, and (3) infra-littoral sediment (see Figure 1). Samples were collected from the surface layer of sediment $(3 \mathrm{~cm})$ to determine the concentration of nutrients, i.e. carbon $(\mathrm{C})$, nitrogen $(\mathrm{N})$ and phosphorus (P) and $\mathrm{CH}_{4}$, and determination of methanogenic activity.

\subsection{Concentration of methane in the sediment}

In the field, $5 \mathrm{~mL}$ of sediment were placed in $25 \mathrm{~mL}$ glass vials $(\mathrm{n}=3)$, containing $5 \mathrm{~mL}$ of concentrated sodium chloride solution to expel methane contained in the sediment. The vials were sealed and transported to the laboratory, where $1 \mathrm{~mL}$ of the headspace of the bottle was removed with a syringe to determine methane concentration by gas chromatography. Methane was quantified on a Varian Star 3400 (Varian Co., USA) gas chromatograph equipped with a FID detector $\left(200{ }^{\circ} \mathrm{C}\right.$ and injector at $\left.120^{\circ} \mathrm{C}\right)$ and a Poropak-Q $1 \mathrm{~m}(60 / 100 \mathrm{mesh})$ column $\left(65^{\circ} \mathrm{C}\right)$ with $\mathrm{N}_{2}$ gas as carrier gas.

\subsection{Methanogenesis}

In the laboratory, $5 \mathrm{~g}$ of sediment were incubated in $25 \mathrm{~mL}$ glass vials $(\mathrm{n}=3)$ with $5 \mathrm{~mL}$ of water of the mangrove, previously filtered through $0.2 \mu \mathrm{m}$ membrane filters. The vials were closed and sealed, and $\mathrm{N}_{2}$ was flowed for 2 minutes to establish an anoxic environment and expel the methane present in the vial. The concentrations of $\mathrm{CH}_{4}$ in the vial headspace were monitored regularly according to the methodology described above, until $\mathrm{CH}_{4}$ concentrations stabilised.

\subsection{Concentration of nutrients in the sediment}

For determination of $\mathrm{C}, \mathrm{N}$ and $\mathrm{P}$ in sediment samples were dried at $50{ }^{\circ} \mathrm{C}$ until constant weight. After maceration, the total nitrogen content was determined according to Allen et al. (1974) and total phosphorus according to Fassbender (1973). For total carbon determination, we used the solid unit of a 5000 TOC Analyzer (Shimadzu Co., Japan).

\subsection{Statistical analysis}

The results of methane concentration in the sediment and nutrients, as well as methanogenesis, were analysed using the nonparametric Kruskal-Wallis and Dunn's post-test. We used a significance level of $95 \%$. Tests were performed using GraphPad Instat 3.0 (GraphPad Software Co.).

\section{Results and Discussion}

The highest concentration of methane in the sediment was found at station 1 and it was significantly higher $(\mathrm{p}<0.05)$ than at station 3 (see Figure 2a). Results obtained in other degraded mangroves have shown high concentrations of methane compared to non-degraded mangroves (see Table 1). However, although the Coroa Grande mangrove ecosystem is impacted by the uncontrolled urban expansion that Sepetiba Bay has suffered, the values of methane concentration found were low compared to other environments altered by human activities. The difference between the concentration of methane found in this study and those of other studies in mangroves can be attributed to the sampling site, which was restricted to the transition area from the sea to the mangrove forest, contrary to most studies that consider the interior mangrove, where there is less leaching of litter and soil oxygenation by tides and higher values of carbon, nitrogen and phosphorus (Sherman et al., 1998). The substrate of the inner area of the mangrove forest is usually composed of large amounts

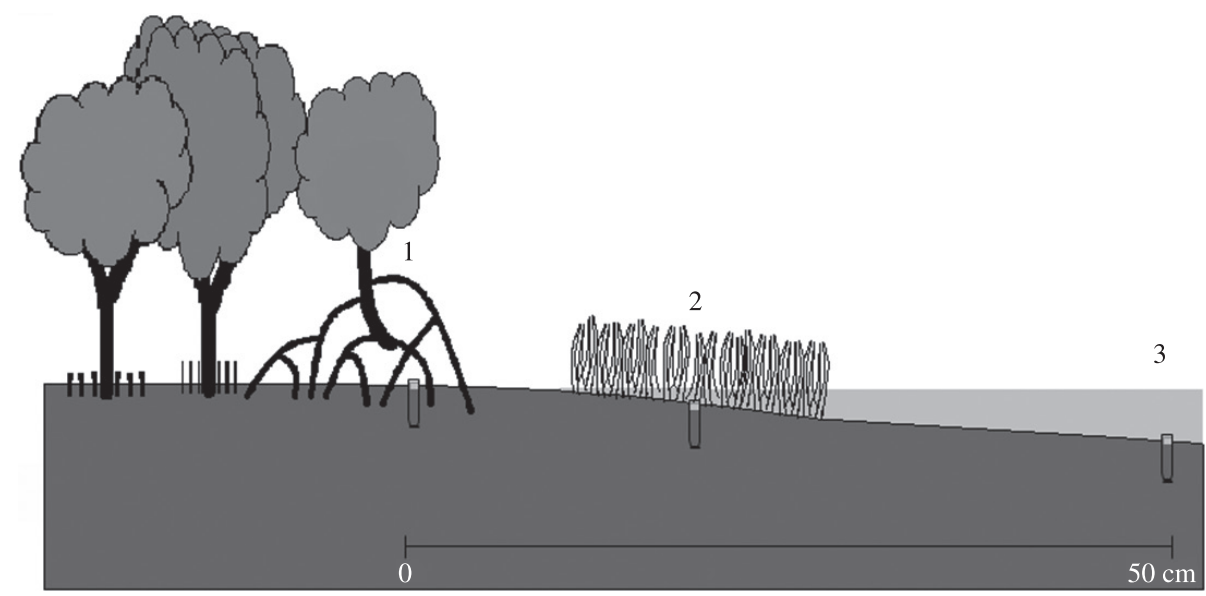

Figure 1. Scheme of sampling area along the transect in Coroa Grande mangrove. Sampling stations: Within mangrove vegetation (1), area colonised by macrophytes (2) and bare soil (3). 


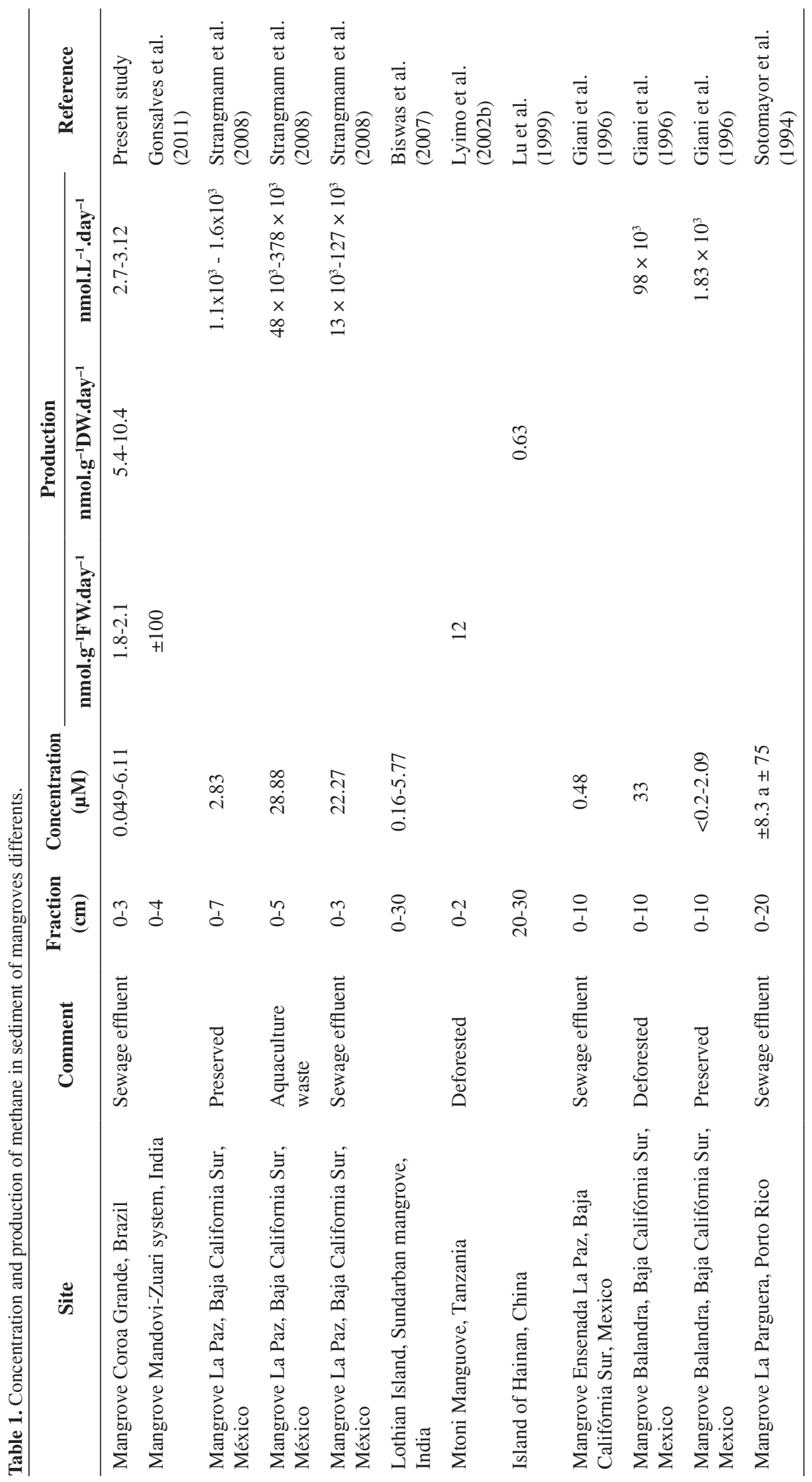


of silt and clay that act as filters retaining OM ( $>5 \%$ of particulate organic carbon), while the border area has little $\mathrm{OM}(<3 \%$ particulate organic carbon) and higher sand content (Kristensen, 2007). Bernini et al. (2006) analysed the texture of mangrove sediments at the Rio São Mateus estuary, Espírito Santo, Brazil, finding the highest OM\% in sediments with smallest particle size, while the more sandy sediment had lower levels of nutrients. Sotomayor et al. (1994) studied the mangrove forest of La Parguera, Puerto Rico, and found low methane concentrations in its border area. Lu et al. (1999) also found lower values of methane production at the sediment surface area at the edge of a mangrove forest in Hainan Island, China. This result was attributed to the more recent origin of the superficial part of sediment from the border area, which suffers more tidal influence than the transition area and the inside of the mangrove. Another relevant question regards the sampled sediment portion: while our study used the 0-3 cm layer of the sediment, many of the studies presented in Table 1 were performed in the $0-30 \mathrm{~cm}$ layer of sediment. As the concentration of methane in sediment is directly related to the competition between methanogens and sulfate reducers and denitrifiers, methane concentrations tend to increase with sediment depth.
The origin of $\mathrm{C}$ in mangrove ecosystems varies according to tidal cycles, at high tide there is a greater contribution of marine material, while at low tide the autochthonous $\mathrm{C}$ prevails, thus influencing the quality of the MO present in the sediment surface (Lacerda et al., 1988). According to Lacerda et al. (1988), from the $\delta^{13} \mathrm{C}$ analysis of the material in suspension and different components of the Coroa Grande mangrove, it was observed that mangrove leaves are the main source of sediment $\mathrm{C}$ and suspended matter of mangrove. In this study, the $\mathrm{C}$ concentration showed the same pattern obtained for the methane concentration with significant difference $(\mathrm{p}<0.05)$ between stations 1 and 3 (see Figure 2b). The values of N (see Figure $2 c$ ) and P (see Figure 2d) concentrations were not significantly different between seasons $(\mathrm{p}>0.05)$. Regarding the molar ratios higher values of $\mathrm{C}: \mathrm{N}, \mathrm{C}: \mathrm{P}$ and $\mathrm{N}: \mathrm{P}$ were observed in a season. Confirming the results found by Lacerda et al. (1988), the contents of $\mathrm{C}, \mathrm{N}$ and $\mathrm{P}$ indicate a greater predominance of autochthonous material in the composition of Coroa Grande mangrove substrate, characteristic of the period of low tide. Most mangrove sediments show $\mathrm{C}: \mathrm{N}$ ratio $>10$, indicating that this sediment is composed mostly of autochthonous material (Kristensen et al., 2008), however, when by human interference these ecosystems receive additional nutrients such as sewage and chemical fertilizers used

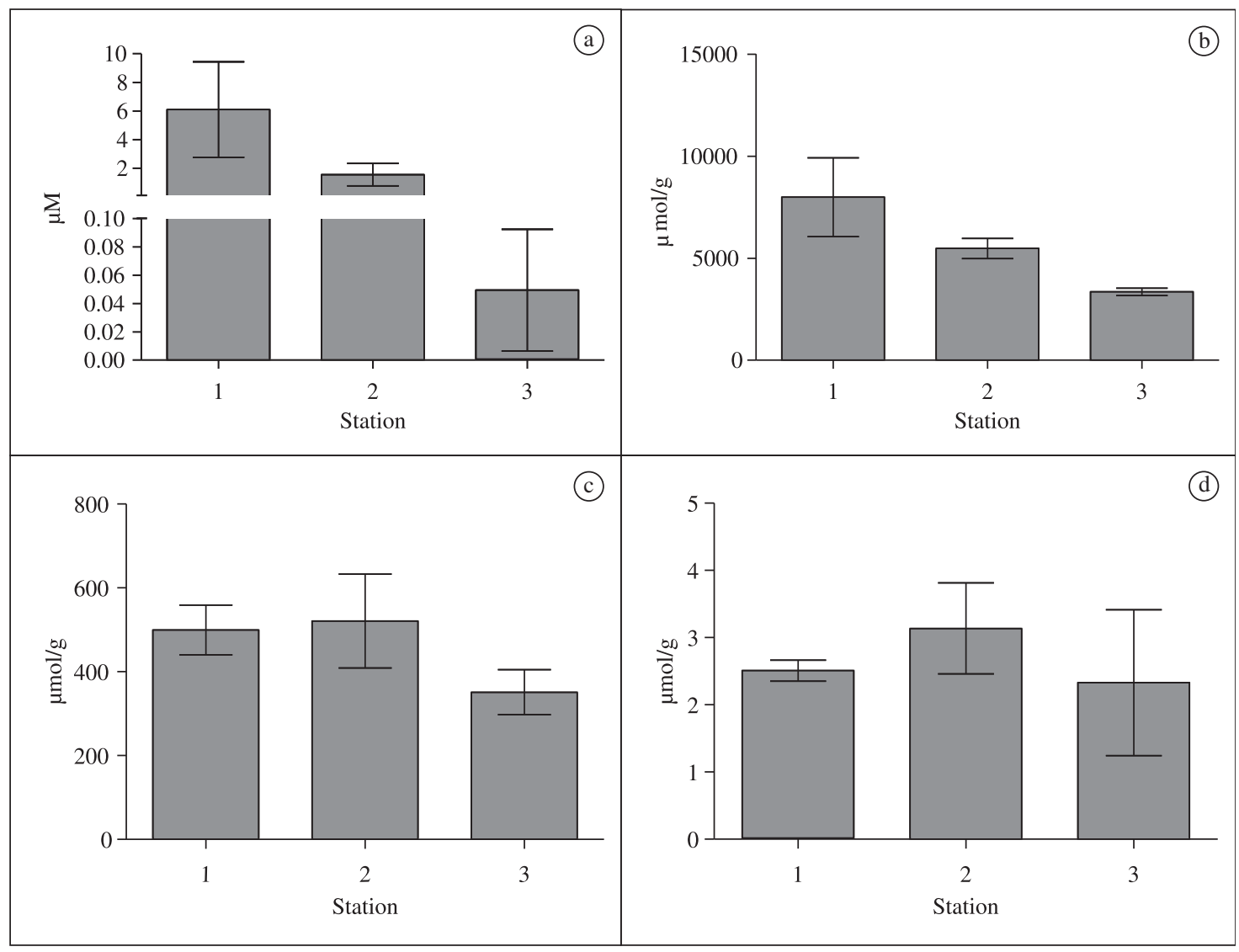

Figure 2. Concentration of Methane (a), Carbon (b), Nitrogen (c) and Phosphorus (d) in the sediment at three sampling stations in Coroa Grande mangrove. 
in agriculture, the availability of nutrients rises and may exacerbate the emission of methane (Purvaja and Ramesh, 2001). Although according to the literature, substrates rich in $\mathrm{N}$ and $\mathrm{P}$ have a tendency to have higher methanogenic activity, in the present study we observed that the highest methane concentrations occurred at stations that had the greatest $\mathrm{C}: \mathrm{N}$ and $\mathrm{C}: \mathrm{P}$ (see Table 2), suggesting that the large amount of organic carbon provided by mangrove vegetation has provided plenty of material available for methanogenesis, with OM quantity becoming more important than its quality to maintain the process. This higher $\mathrm{C}$ concentration in the sediment of station 1 (see Figure $2 \mathrm{~b}$ ) reflects the contribution of biomass that tends to be relatively higher near the ground and lower toward the sea (Komiyama et al., 2008), making the substrate a limiting factor for methanogenesis due to the low $\mathrm{OM}$ availability (Sotomayor et al., 1994).

The key factors for methanogenesis are the absence of oxygen and $\mathrm{OM}$ availability, so variations in these factors depending on the different sites may have contributed to differences in results between the stations. As a consequence of the large supply of OM in a station, depending on the values of $\mathrm{C}$, this area may have a reduced oxygen concentration in the subsurface due to intense aerobic decomposition of OM, creating conditions for methanogenesis, and inhibiting the oxidation of methane by methanotrophic bacteria. But the availability of $\mathrm{OM}$ in station 1 was not significantly different $(p>0.05)$ between sampling stations, as can be seen in the early days in the curve of methane production (see Figure 3), likely due to competition between methanogens and sulfate reducers. The probable

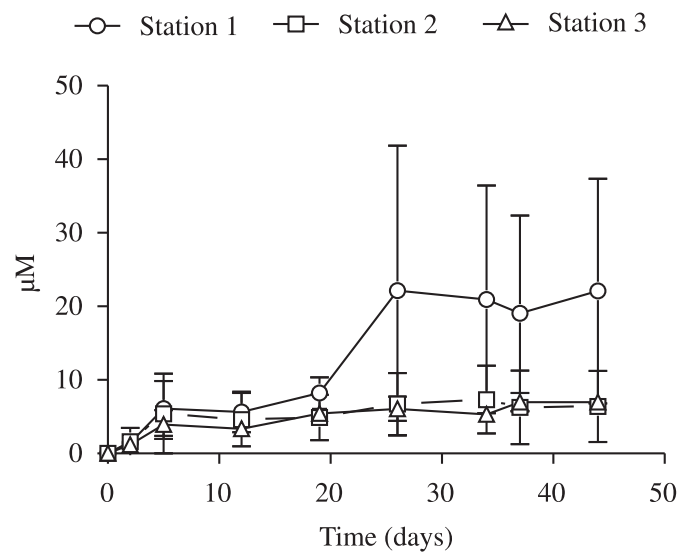

Figure 3. Variation of concentrations of methane in the headspace of vials during the incubation period to determine potential methane production in sediment Coroa Grande mangrove. cause for the different values of methane concentration between stations would be a greater distance from station 1 over the sea, which provides less frequent floods, and through evaporation, increases the concentration of salt in the substrate (Bouillon et al., 2007). This leads to a lower solubility of gases in the pore water (Minello, 2004), such as oxygen, and therefore decreases methanotrophy. Moreover, this distance decreases the uptake of sulfate reducing anaerobic oxidation of methane through the consortium with sulfate reducing organisms, contributing to the highest concentration of methane found at this station.

Sulfate and salinity have negative effect on methanogenesis (Lu et al., 1999), so environments that have a strong marine influence, such as mangroves, are not considered major sources of methane because of the high concentration of salt and sulfate from sea water (Purvaja and Ramesh, 2001). Despite being higher than the values found for stations 2 and 3 , methane concentration at station 1 is not considered high. Low concentrations of methane were also observed in a study conducted in an anthropogenically disturbed mangrove at La Paz, Mexico, indicating that methanogenesis is balanced by the processes of oxidation of methane in the sediment (Giani et al., 1996). In a pristine mangrove at Bengal Bay, India, the maximum methane concentration of the pore water $(5.769 \mu \mathrm{M})$ was low, suggesting intense competition between oxidation and methanogenic and sulfate-reducing bacteria and nitrate (Biswas et al., 2007).

Though the initial values of methanogenesis were not significantly different $(\mathrm{p}>0.05)$, there was a greater production of methane in sediments from stations 1 and 2 (see Figure 3). The salinity in this case does not appear to interfere with the results, since the incubation of all the sediments was done with water collected from the same point, equaling salinities. Considering the presence of sulfate ions, the values of methane produced during the incubation period of sediment at station 1 indicates a possible competition for substrate in the early days between methanogenic and sulfate reducing organisms. In the early days of incubation the interaction between organisms seems to favour sulfate reduction. As sulfate-reducing bacteria are more competitive than the methanogens for substrates that are common to both organisms, they maintain low concentrations of these substrates for methanogens (Lyimo et al., 2002a). However, after the second week, there was a probable decline in the amount of sulfate available that provided a significant increase at methanogenesis $(\mathrm{p}<0.05)$ observed in the twenty-sixth day of the experiment (see Figure 3), especially in relation to station 1, probably due to increased availability of OM. Experiments developed by Lyimo et al. (2002a) show that although acetate and

Table 2. Molar ratios C:N, C:P and N:P in the sediment at sampling stations of Mangrove Coroa Grande.

\begin{tabular}{ccccc}
\hline Station & Feature & C:N & C:P & N:P \\
\hline 1 & Presence of mangrove vegetation & 16 & 3185 & 199 \\
2 & Colonised by aquatic macrophytes & 10.5 & 1747 & 166 \\
3 & Bare soil and and permanently flooded & 9.6 & 1439 & 151 \\
\hline
\end{tabular}


formate have stimulated methanogenesis and sulfate reduction, only some of these substrates were converted into methane. However, inhibition of bacterial sulfate reduction resulted in complete conversion of substrates to methane. Mohanraju et al. (1997) reported that methane produced in the mangrove sediments is probably derived from methylated amines, compounds that are not used by sulfate reducing bacteria.

\section{Conclusion}

This study provided results regarding the production and concentration of methane in a coastal ecotone in southeastern Brazil. The research hypothesis was rejected, because the quantity and quality of $\mathrm{OM}$ were not the main factors in increasing the activity of methanogens in the sediment sampling stations. The results indicate a gradient of methane dynamics in the sampling stations, where other factors may regulate methanogenesis. This study concludes that the concentration of methane in the transition area from sea to land in the Coroa Grande mangrove is a function of the amount of $\mathrm{C}$ available in the various sampling sites, determined mainly by the presence of vegetation, indicating a possible negative effect on methanotrophy. Facing the progressive unregulated population growth in the region of the Sepetiba Bay that contributes to a continuous increase of OM in this ecosystem by the disposal of raw sewage into water bodies bordering mangroves, the methanogenesis regulating factors tend to be less expressive.

Acknowledgements - The authors thank FAPERJ and CNPq for financial support for our research. Irene Freitas and Luiz Cesar gave valuable logistical support during sample collection. Adriana de Melo Rocha helped improve the English manuscript version.

\section{References}

ALLEN, DE., DALAL, RC., RENNENBERG, H., MEYER, RL., REEVES, S. and SCHMIDT, S., 2007. Spatial and temporal variation of nitrous oxide and methane flux between subtropical mangrove sediments and the atmosphere. Soil Biology \& Biochemistry, vol. 39, no. 2, 622-631. http://dx.doi.org/10.1016/j.soilbio.2006.09.013

ALLEN, SE., GRIMSHAW, HM., PARKINSON, JA. and QUARMBY, C., 1974. Chemical analysis of ecological material. Oxford: Blackwell Scientific Publications. 565 p.

BERNINI, E., SILVA, MAB., CARMO, TMS. and CUZZUOL, GRF., 2006. Composição química do sedimento e de folhas das espécies do manguezal do estuário do rio São Mateus, Espírito Santo, Brasil. Revista Brasileira de Botânica, vol. 29, p. 689-699.

BISWAS, H., MUKHOPADHYAY, SK., SEN, S. and JANA, TK., 2007. Spatial and temporal patterns of methane dynamics in the tropical mangrove dominated estuary, NE coast of Bay of Bengal, India. Journal of Marine Systems, vol. 68, no. 1-2, p. 55-64. http://dx.doi.org/10.1016/j.jmarsys.2006.11.001

BOUILLON, S., MIDDELBURG, JJ., DEHAIRS, F., BORGES, AV., ABRIL, G., FLINDT, MR., ULOMI, S. and KRISTENSEN, E., 2007. Importance of intertidal sediment processes and porewater exchange on the water column biogeochemistry in a pristine mangrove creek (Ras Dege, Tanzania). Biogeosciences, vol. 4, no. 3, p. 311-322. http://dx.doi.org/10.5194/bg-4-311-2007

COIMBRA, AG., 2003. Distribuíção de metais pesados em moluscos e sedimentos nos manguezais de Coroa Grande e da Enseada das Garças, Baía de Sepetiba, RJ. Rio de Janeiro: Universidade Federal Fluminense. 72 p. Dissertação de Mestrado em Geoquímica Ambiental.

EL-FADEL, M. and MASSOUD, M., 2001. Methane emissions from wastewater management. Environmental Pollution, vol. 114, no. 2, p. 177-185. http://dx.doi.org/10.1016/S0269-7491(00)00222-0

FASSBENDER, HW., 1973. Simulate P-Bestinmung in N-Kjeldahl Ausfschlub von Bodenproben. Die Phosphörsäure, vol. 30, p. 44-53.

FERRY, JG., 1993. Methanogenesis: ecology, physiology, biochemistry \& genetics. New York: Chapman \& Hall. 536 p.

GIANI, L., BASHAN, Y., HOLGUIN, G. and STRANGMANN, A., 1996. Characteristics and methanogenesis of the Balandra lagoon mangrove soils, Baja California Sur, Mexico. Geoderma, vol. 72, no. 1-2, p. 149-160. http://dx.doi.org/10.1016/00167061(96)00023-7

GONSALVES, MJ., FERNANDES, CEG., FERNANDES, SO., KIRCHMAN, DL and BHARATHI, PAL., 2011. Effects of composition of labile organic matter on biogenic production of methane in the coastal sediments of the Arabian Sea. Environmental Monitoring and Assessment, vol. 175/2011, p. 11.

HINRICHS, KU., SUMMONS, RE., ORPHAN, V., SYLVA, SP. and HAYES, JM., 2000. Molecular and isotopic analysis of anaerobic methane-oxidizing communities in marine sediments. Organic Geochemistry, vol. 31, no. 12, p. 1685-1701. http://dx.doi. org/10.1016/S0146-6380(00)00106-6

Intergovernmental Panel on Climate Change - IPCC, 2001. Contribution of Working Group I to the Third Assessment Report of the Intergovernmental Panel on Climate Change. Cambridge: Cambridge University Press. 873 p.

-, 2007. Contribution of Working Groups I, II and III to the Fourth Assessment Report of the Intergovernmental Panel on Climate Change. Geneva: IPCC. 104 p.

KOMIYAMA, A., ONG, JE. and POUNGPARN, S., 2008. Allometry, biomass, and productivity of mangrove forests: A review. Aquatic Botany, vol. 89, no. 2, p. 128-137. http://dx.doi. org/10.1016/j.aquabot.2007.12.006

KREUZWIESER, J., BUCHHOLZ, J. and RENNENBERG, H., 2003. Emission of methane and nitrous oxide by Australian mangrove ecosystems. Plant Biology, vol. 5, no. 4, p. 423-431. http://dx.doi.org/10.1055/s-2003-42712

KRISTENSEN, E., 2007. Carbon balance in mangrove sediments: the driving processes and their controls. In TATEDA, Y., UPSTILLGODDARD, R., GOREAU, T., ALONGI, D., NOSE, A., KRISTENSEN, E. and WATTAYAKORN, G. (Eds.). Greenhouse gas and carbon balances in mangrove coastal ecosystems. Toky: Maruzen. p. 61-78.

KRISTENSEN, E., BOUILLON, S., DITTMAR, T. and MARCHAND, C., 2008. Organic carbon dynamics in mangrove ecosystems: A review. Aquatic Botany, vol. 89, no. 2, p. 201-219. http://dx.doi.org/10.1016/j.aquabot.2007.12.005

KRITHIKA, K., PURVAJA, R. and RAMESH, R., 2008. Fluxes of methane and nitrous oxide from an Indian mangrove. Current Science, vol. 94, no. 2, p. 218-224. 
KRUPADAM, RJ., AHUJA, R., WATE, SR. and ANJANEYULU, Y., 2007. Forest bound estuaries are higher methane emitters than paddy fields: A case of Godavari estuary, East Coast of India. Atmospheric Environment, vol. 41, no. 23, p. 4819-4827. http:// dx.doi.org/10.1016/j.atmosenv.2007.02.023

LACERDA, LD., MARTINELLI, LA., REZENDE, CA., MOZETTO, AA., OVALLE, ARC., VICTORIA, RL., SILVA, CAR. and NOGUEIRA, FB., 1988. The fate of trace metals in suspended matter in a mangrove creek during a tidal cycle. The Science of the Total Environment, vol. 75, p. 169-180. http://dx.doi. org/10.1016/0048-9697(88)90030-7

LACERDA, LD., ITTEKKOT, V. and PATCHINEELAM, SR., 1995. Biogeochemistry of mangrove soil organic matter: a comparison between rhizophora and avicennia soils in South-eastern Brazil. Estuarine Coastal and Shelf Science, vol. 40, no. 6, p. 713-720. http://dx.doi.org/10.1006/ecss.1995.0048

LYIMO, TJ., POL, A. and DEN-CAMP, HJMO., 2002a. Sulfate reduction and methanogenesis in sediments of Mtoni mangrove forest, Tanzania. AMBIO, vol. 31, no. 7-8, p. 614-616. PMid:12572833.

-, 2002b. Methane Emission, Sulphide Concentration and Redox Potential Profiles in Mtoni Mangrove Sediment, Tanzania. Western Indian Ocean Journal of Marine Science, vol. 1, no. 1, p. 71-80.

LU, CY., WONG, YS., TAM, NFY., YE, Y. and LIN, P., 1999. Methane flux and production from sediments of a mangrove wetland on Hainan IslandChina. Mangroves Salt Marshes, vol. 3, no. 1, p. 41-49. http://dx.doi.org/10.1023/A:1009989026801

MEULEPAS, RJW., JAGERSMA, CG., KHADEM, AF., STAMS, AJM. and LENS, PNL., 2010. Effect of methanogenic substrates on anaerobic oxidation of methane and sulfate reduction by an anaerobic methanotrophic enrichment. Applied Microbiology and Biotechnology, vol. 87, no. 4, p. 1499-1506. PMid:20445975 PMCid:2892604. http://dx.doi.org/10.1007/s00253-010-2597-0

MINELLO, M., 2004. Metanogênese sob a variação de salinidade em lagoas costeiras do Norte Fluminense: implicações nas condições osmóticas e na competição por substratos. Rio de Janeiro: Universidade Federal do Rio de Janeiro (UFRJ). 66 p. Dissertação de Mestrado em Ecologia.

MOHANRAJU, R., RAJAGOPAL, BS. and DANIELS, L., 1997. Isolation and characterization of a methanogenic bacterium from mangrove sediments. Journal of Marine Biotechnology, vol. 5, no. $2-3$, p. $147-152$

MOLISANI, MM., MARINS, RV., MACHADO, W., PARAQUETTI, HHM., BIDONE, ED. and LACERDA, LD., 2004. Environmental changes in SepetibaBay, SE Brazil. Regional Environmental Change, vol. 4 n. 1, p. 17-27. http://dx.doi.org/10.1007/s10113-003-0060-9
NGUYEN, TD., CRILL, P. and BASTVIKEN, D., 2010. Implications of temperature and sediment characteristics on methane formation and oxidation in lake sediments. Biogeochemistry, vol. 100, no. 1-3, p. 185-196. http://dx.doi.org/10.1007/s10533-010-9415-8

PURVAJA, R. and RAMESH, R., 2001. Natural and anthropogenic methane emission from coastal wetlands of South India. Environmental Management, vol. 27, no. 4, p. 547-557. PMid:11289453. http:// dx.doi.org/10.1007/s002670010169

PURVAJA, R., RAMESH, R. and FRENZEL, P., 2004. Plant-mediated methane emission from an Indian mangrove. Global Change Biology, vol. 10 , no. 11 , p. 1825-1834. http://dx.doi.org/10.1111/j.13652486.2004.00834.x

SCHAEFFER-NOVELLI, Y., 1995. Manguezal Ecossistema entre a terra e o mar. São Paulo: Editora Caribbean Ecological Research. 64 p.

SCHAEFFER-NOVELLI, Y., COELHO JUNIOR, C. and TOGNELLA-DE-ROSA, M., 2002. Manguezais. São Paulo: Ática. $48 \mathrm{p}$.

SCHUBERT, CJ., LUCAS, FS., DURISCH-KAISER, E., STIERLI, R., DIEM, T., SCHEIDEGGER, O., VAZQUEZ, F. and MÜLLER, B., 2010. Oxidation and emission of methane in a monomictic lake (Rotsee, Switzerland). Aquatic Sciences, vol. 72, no. 4, p. 455-466. http://dx.doi.org/10.1007/s00027-010-0148-5

SEGERS, R., 1998. Methane production and methane consumption: a review of processes underlying wetland methane fluxes. Biogeochemistry, vol. 41, no. 1, p. 23-51. http://dx.doi. org/10.1023/A:1005929032764

SHERMAN, RE., FAHEY, TJ. and HOWARTH, RW., 1998. Soil-plant interactions in a neotropical mangrove forest: iron, phosphorus and sulfur dynamics. Oecologia, vol. 115, no. 4, p. 553-563. http://dx.doi.org/10.1007/s004420050553

SOTOMAYOR, D., CORREDOR, JE. and MORELL, JM., 1994. Methane flux from mangrove sediments along the southwestern coast of Puerto-Rico. Estuaries, vol. 17, no. 1B, p. 140-147. http:// dx.doi.org/10.2307/1352563

STRANGMANN, A., BASHAN, Y. and GIANI, L., 2008. Methane in pristine and impaired mangrove soils and its possible effect on establishment of mangrove seedlings. Biology and Fertility of Soils, vol. 44, no. 3, p. 511-519. http://dx.doi.org/10.1007/ s00374-007-0233-7

TOMLINSON, PB., 1994. The Botany of Mangroves. Cambridge: Cambridge University Press. 419 p. 